\title{
Diabetes Type II and Covid-19: Need of Rethinking
}

\author{
Cornelli Umberto* \\ Loyola University School of Medicine, Chicago \\ Submission: January 25, 2020; Published: February 04, 2020 \\ *Corresponding author: Cornelli Umberto, Loyola University School of Medicine, Chicago
}

Keywords: Diabetes; Covid-19; Infectious disease; Aging; WHO records; Insulin resistance; Risk factor; ACE2 receptors

\section{Introduction}

In the medical literature, the association between diabetes type II and COVID-19 has been analyzed several times [1-9] with almost the common finding that the disease is a risk factor for COVID-19 infection and death. The increase of ACE2 receptors in diabetic patients $[2,4,6$,$] has been considered as one of the major$ causes, together with the inflammatory condition and insulin resistance which are common characteristics of diabetes type II $[5,6]$. Some authors were mentioning that the poorly controlled diabetes represents a risk factor for any infectious disease [8,9]. All these data, despite giving an important contribution to the

Table 1: COVID-19 deaths $x 1000$ people and diabetes type II ASDRs.

\begin{tabular}{|c|c|c|c|c|c|}
\hline Country & $\begin{array}{c}\text { COVID-19 Death } \\
\times 10^{3}\end{array}$ & $\begin{array}{c}\text { Diabetes Type II } \\
\text { ARDRs }\end{array}$ & Country & $\begin{array}{c}\text { COVID-19 Death } \\
\times 10^{3}\end{array}$ & $\begin{array}{c}\text { Diabetes Type II } \\
\text { ASDRs }\end{array}$ \\
\hline Armenia & 1.001 & 27.445 & Kyrgyzstan & 0.236 & 10.351 \\
\hline Australia & 0.039 & 9.595 & Latvia & 0.516 & 10.894 \\
\hline Austria & 0.851 & 14.181 & Lithuania & 0.831 & 5.006 \\
\hline Bahamas & 0.475 & 28.002 & Luxembourg & 1.022 & 7.647 \\
\hline Belgium & 1.845 & 5.623 & Malta & 0.574 & 15.493 \\
\hline Brazil & 1.05 & 30.342 & Mauritius & 0.008 & 146.305 \\
\hline Brunei & 0.007 & 52.972 & Mexico & 1.206 & 91.405 \\
\hline Canada & 0.516 & 9.104 & Netherlands & 0.793 & 7.443 \\
\hline Chile & 0.987 & 20.534 & New Zealand & 0.006 & 10.513 \\
\hline Croatia & 1.107 & 17.474 & Norway & 0.105 & 5.989 \\
\hline Cuba & 0.016 & 12.086 & Republic of Chorea & 0.026 & 13.898 \\
\hline Czechia & 1.421 & 15.763 & Moldova & 0.812 & 8.708 \\
\hline
\end{tabular}

understanding of the matter, most of the time are related to one country only.

In the following table are reported the data of 49 Countries in relation to the deaths for COVID-19 x 1000 people (updated to January $21^{\text {st }}, 2021$ [10]) and the ASDR (Age Standardized Death Ratio) for diabetes type II. ASDRs are measures of the disease's frequency in the countries and are purposely calculated to compare the data among countries [11] (Table 1). A significant negative correlation $(\mathrm{r}=-0.3008 \mathrm{p}<0.05)$ was found between diabetes type II and COVID-19 deaths, which is exactly the opposite of the common believe. 


\section{Current Research in Diabetes \& Obesity Journal}

\begin{tabular}{|c|c|c|c|c|c|}
\hline Denmark & 0.331 & 11.387 & Romania & 0.877 & 0.018 \\
\hline Estonia & 0.269 & 5.378 & Saint Vincent \& Grenadinas & 0.701 & 88.45 \\
\hline Finland & 0.116 & 4.298 & Slovakia & 1.579 & 9.995 \\
\hline France & 0.619 & 6.831 & Slovenia & 1.179 & 6.571 \\
\hline Germany & 0.619 & 9.994 & Spain & 1.108 & 6.822 \\
\hline Grenada & 0.009 & 78.995 & Sweden & 1.083 & 8.284 \\
\hline Guatemala & 0.338 & 68.261 & Switzerland & 1.325 & 6.085 \\
\hline Hungary & 1.186 & 13.283 & Macedonia & 0.099 & 1.477 \\
\hline Iceland & 0.088 & 4.506 & Trinidad and Tobago & 1.274 & 4.982 \\
\hline Ireland & 0.6 & 6.868 & United Kingdom & 0.02 & 15.584 \\
\hline Israel & 0.501 & 20.99 & USA & $-0.3008 \mathrm{p}<0.05$ & 27.402 \\
\hline Italy & 1.421 & 10.867 & Uzbekistan & \\
\hline Japan & 0.038 & 3.339 & r COVID-19 VS Diabetes type 2 & \\
\hline
\end{tabular}

\section{Limitations of the Study}

The ASDRs of diabetes type II were those of the year 2016, because the WHO records are not updated (maybe they are, but data are not anymore publically available). However, the ASDRs correlations between values from 2000 and 2016 are very high ( $r=0.9641$ ) which means that data of 2016 represent a reliable measure of 2020 also [12]. The cut-off of the statistical significance was settled to $\mathrm{p}<0.05$. This can be a further limitation, since in many studies the value of $\mathrm{p}<0.01$ is preferred which of course is more solid (personally I am used to choose this cut-off for correlations). However, no matter about the cut-of limit, the correlation of diabetes type II with COVID-19 death is negative and not positive.

\section{Conclusion}

A negative correlation was found with diabetes type II and COVID-19 deaths, meaning that the disease cannot be considered a threat for COVID-19. One may not rule out that a combination of aging, diabetes and other diseases can represent a risk for COVID-19 death. However, aging, and concomitant chronic illnesses increase the odds ratio of death for any disease.

\section{References}

1. Barron E, Bakhai C, Kar P, Andy Weaver, Dominique Bradley, et al. (2020) Association of type 1 and type 2 diabetes with COVID-19related mortality in England: a whole- population study. Lancet Diabe Endoc 8: 813-822.
2. Fang L, Karakiulakis G, Roth M (2020) Are patients with hypertension and diabetes mellitus at increased risk for COVID-19 infection? Lancet respir $8(4)$.

3. Orioli L, Hermans MP, Thissen JP, Dominique Maiter, Bernard Vandeleene, et al. (2020) COVID-19 in diabetic patients: related risk and specifics of management. Ann Endocr 81: 101-109.

4. Rajpal A, Rahimi L, Ismail Beigi F (2020) Factors leading to high morbidity and mortality of COVID-19 in patients with type 2 diabetes. J Diabetes.

5. Bornstein SR, Rubino F, Khunti K, Geltrude Mingrone, David Hopkins, et al. (2020) Practical recommendations for the management od diabetes in patients with COVID-19. Lancet Diabetes Endocrinol (6): 546-550.

6. Druker DJ (2020) Coronavirus infection and type 2 diabetes-shared pathways with therapeutic implications. Endocr Rev 41(3): bnaa011.

7. Zhu L, She Z.G, Cheng Z, Juan Juan Qin, Xiao Jing Zhang, et al. (2020) Association of blood glucose control and outcomes in patients with COVID-19 and pre-existing type 2 diabetes. Cell Metab 31(6): 10681077.

8. Erener S (2020) Diabetes, infection risk and COVID-19. Mol Metab 39:101044.

9. Papazafiropoulou A, Antonopulous S (2020) The Covid-19 pandemic and diabetes mellitus. Arch Med Sci Atheroscl Dis 5: e200-e205.

10. John Hopkins Coronavirus Resource Center.

11. Global health Estimates 2016 death by Cause Age Sex by Country and by Region 200-2016. Geneva World Health Organization. 2108.

12. Cornelli U, Belcaro G, Cesarone MR, Recchia M, Cotellese R (2020) Covid-19 aging and chronic diseases. Microb Infect Dis 4(4): 1-6. 
This work is licensed under Creative Commons Attribution 4.0 Licen DOI: 10.19080/CRDOJ.2021.14.5580

Your next submission with Juniper Publishers
will reach you the below assets
- Quality Editorial service
- Swift Peer Review
- Reprints availability
- E-prints Service
- Manuscript Podcast for convenient understanding
- Global attainment for your research
- Manuscript accessibility in different formats
( Pdf, E-pub, Full Text, Audio)
- Unceasing customer service
Track the below URL for one-step submission
https://juniperpublishers.com/online-submission.php

